\title{
Comparison of Brown Midrib Sorghum with Conventional Sorghum Forage for Grazing Dairy Cows
}

\author{
Laura Astigarraga, Ana Bianco, Ricardo Mello, Dana Montedónico \\ Department of Animal Production and Pastures, Faculty of Agronomy, University of the Republic, Montevideo, \\ Uruguay \\ Email: astigarr@fagro.edu.uy
}

Received 19 January 2014; revised 21 February 2014; accepted 4 March 2014

Copyright (C) 2014 by authors and Scientific Research Publishing Inc.

This work is licensed under the Creative Commons Attribution International License (CC BY). http://creativecommons.org/licenses/by/4.0/

\section{Open Access}

\begin{abstract}
A brown midrib (BMR) sorghum pasture was compared with normal sorghum for its effects on performance of Holstein cows in midlactation in terms of milk production and composition at grazing over three periods (Period 1: 20/01 to 31/01, Period 2: 17/02 to 28/02, Period 3: 19/03 to $30 / 03)$. Forty Holstein cows were grouped according to pre-experimental milk production (22.4 $\pm 4.2 \mathrm{~kg} / \mathrm{d}$ milk), live weight (530 $\pm 25 \mathrm{~kg})$ and lactation stage $(127 \pm 63$ days) and assigned randomly to one of the two experimental pasture. Pasture was assigned on equal basis at an allowance $25 \mathrm{~kg} \mathrm{DM} / \mathrm{cow} /$ day (above $10 \mathrm{~cm}$ ), assuming a 65\% forage utilization and cows received $4 \mathrm{~kg}$ of concentrate per day. Simultaneously, both pastures were evaluated with sheep, to analyze digestibility at every grazing period. The BMR sorghum supported higher FCM than normal sorghum (18.5 vs. $17.8 \mathrm{l} /$ day, $\mathrm{P}<\mathbf{0 . 0 5}$ ). Additionally, production of milk components was greater +52 $\mathrm{g} / \mathrm{day} / \mathrm{cow}$ and $+36 \mathrm{~g} / \mathrm{day} / \mathrm{cow}$ for fat and protein respectively, $\mathrm{P}<0.05$ ), with fewer intake of concentrate $(-0.4 \mathrm{~kg} /$ day $/$ cow, $\mathrm{P}<0.05)$ when compared with cows grazing normal sorghum. Those results are in accordance with greater $(P<0.05)$ total digestive tract $D M, O M$ and NDF in vivo digestibilities for BMR sorghum $(65.0,67.1,65.9$ respectively) than for normal sorghum $(60.3$, 62.0, 61.3 respectively). The increased digestibility of BMR sorghum must be associated with the compositional differences on fiber which allowed a higher cell wall digestion. Results of this study indicate that the BMR sorghum hybrid outperformed the normal sorghum hybrid resulting in a higher performance per cow with lower concentrate consumption compared with normal sorghum.
\end{abstract}

\section{Keywords}

Brown Midrib; Forage Sorghum; Digestibility; Milk Production; Dairy Cows

How to cite this paper: Astigarraga, L., Bianco, A., Mello, R. and Montedónico, D. (2014) Comparison of Brown Midrib Sorghum with Conventional Sorghum Forage for Grazing Dairy Cows. American Journal of Plant Sciences, 5, 955-962. 


\section{Introduction}

Sorghum [Sorghum bicolor (L.)Moench.] is an important forage crop for grazing dairy cows in many milk producer regions of the world as frequent drought and high summer temperatures reduce forage production from pastures. Forage sorghums can be planted later than corn; use water much more efficiently; and, when exposed to drought, still produce acceptable yields [1].

However, up to $100 \%$ of dry matter production of forage sorghum is non-grain, so quality enhancement of the forage component should contribute significantly to improved animal performance. The decision to select a particular hybrid or variety of forage sorghum is increasingly made on perceived quality. Often these perceptions are based on animal palatability or forage quality, and can outweigh yield in the process of selecting a hybrid or variety for high yielding animals like dairy cows. Brown midrib (BMR) mutants were originally induced and described in sorghum by Porter et al. [2]. This trait is associated with reduced lignin content and/or an increase in forage digestibility expressed in both sorghum and sudangrass [3] and their hybrids [4] [5]. In situ and in vitro digestion studies have shown that BMR forages have greater extent of NDF digestion than their conventional counterparts [6] [7]. Such increases in digestibility are associated with increased animal performance. Several studies observed greater milk production for Holstein dairy cows fed BMR forage sorghum vs. conventional forage sorghum as silage [6] [8] [9]. However, to date, there is no study with dairy cows conducted using brownmidrib sorghum as grazing forage.

The objective of the current study was to quantify the increase in forage quality associated with the brownmidrib trait in sorghum, in comparison with a commercial hybrid, when grown under large scale field conditions, and offered to dairy cows at grazing.

\section{Materials and Methods}

\subsection{Experimental Treatments and Design}

The experiment was carried out in the "Centro Regional Sur”, Experimental Station of the Faculty of Agronomy (34 $\left.{ }^{\circ} 36^{\prime} \mathrm{S}, 56^{\circ} 13^{\prime} \mathrm{W}\right)$, of the Universidad de la República (Canelones, Uruguay) during the summer (January to March 2003). The rainfall on the experimental site was $504 \mathrm{~mm}$ in spring and $187 \mathrm{~mm}$ in summer (34, 133 and $20 \mathrm{~mm}$ in January, February and March respectively). Average daily temperature was $21.7^{\circ} \mathrm{C}$ for the experimental period.

Two sorghum (Sorghum bicolor (L.), Moench) types were examined in our study:the sorghum BMR hybrid Candy Graze (sorghum bicolor x sorghum sudanensis) (BMR) and, the commercial sorghum hybrid Supergauchazo (sorghum bicolor $x$ sorghum sudanensis) (CONTROL) was used as reference variety as it is widely used in Uruguay. Both hybrids, selected based on nutritional value and yield for Uruguayan conditions, were from Druetto Company (Argentina) and supplied by LEBU Seeds (Uruguay).

Forty lactating Holstein cows were used over three 12-day periods to evaluate each hybrid (Period 1: 20/01 to 31/01, Period 2: $17 / 02$ to 28/02, Period 3: 19/03 to 30/03). The animals were allotted to two groups of 20 cows according to pre-experimental milk production $(22.4 \pm 4.2 \mathrm{~kg} / \mathrm{d}$ milk), live weight (530 $\pm 25 \mathrm{~kg})$ and lactation stage (127 \pm 63 days). Each lot was randomly assigned to the treatments in the first period, and remained in their assigned pasture all summer.

Sorghum pastures were strip-grazed at a daily minimum amount of $25 \mathrm{~kg} \mathrm{DM} / \mathrm{cow} /$ day (above $10 \mathrm{~cm}$ ), assuming a 65\% forage utilization [10]. A new area of pasture was offered to the cows once a day after the morning milking. Back-grazing was prevented by electric fencing. Daily areas to be offered were determined by estimating forage availability as described below.

\subsection{Pasture Establishment and Measurements}

The two pastures of sorghum hybrid were sown in the spring 2002 (16 November 2002) in 12-ha area: one half of sorghum BMR and the other half of sorghum CONTROL after an oats crop. The sowing rates were 13 and 20 $\mathrm{kg} / \mathrm{ha}$ for the BMR and the CONTROL hybrid respectively, to achieve a stand of 450.000 plants/ha. The field was tilled to a depth of $15 \mathrm{~cm}$, and was treated pre-sowing with $2.4 \mathrm{~L}$ atrazine/ha to prevent weed germination. A fertilizer dose of $30 \mathrm{~kg} \mathrm{~N} / \mathrm{ha}$ and $70 \mathrm{~kg} \mathrm{P}_{2} \mathrm{O}_{5} /$ ha was applied at sowing.

The pre-grazing forage mass, plant density and morphological composition were measured on days $1,6,10$ and 13 in each pasture. The number of tillers was counted on five random 1-m linear sections of row for each 
hybrid and whole plant samples were taken by hand harvesting (above $10 \mathrm{~cm}$ ). After cutting, plant samples were weighed fresh, and a subsample (approximately half the plants per sample) was dried at $60^{\circ} \mathrm{C}$ for $72 \mathrm{~h}$ for DM determination and subsequent chemical analysis of forage on offer. The other subsample of fresh material was cut into sections of $10 \mathrm{~cm}$, starting from the cut bases. Material of each section was separated into green lamina, stems and panicles, and the quantitative distribution of DM between the organs was determined after drying at $60^{\circ} \mathrm{C}$ for $72 \mathrm{~h}$. These data were used to calculate the proportion of the total forage mass of each morphological unit per $10 \mathrm{~cm}$ stratum, and the proportion of green leaves, stem, and panicles in the whole pasture.

The same procedure was followed for determining the post-grazing forage mass, plant density and morphological composition on days 3, 8, 12 and 15 in each pasture

The mean plant height was measured before and after grazing on the area grazed on days 2, 7, 11 and 14 . At each time, 50 plants were taken at random and the height to ground level was measured. The differences between the two values were used to calculate the mean depth of defoliation for each treatment.

\subsection{Digestibility Experiment with Sheep}

Simultaneously to each grazing period with dairy cows, the digestibility of the offered herbage (cut above $10 \mathrm{~cm}$ ) was measured with twelve Corriedale wethers (6 per treatment) to characterize forage quality. The animals were kept in metabolism crates with free access to water. Each experimental period for the digestibility trial comprised an adjustment period of 7-days, followed by 5-days dedicated to collection of faeces, orts, and feed refusal. For the adjustment period, feed was available ad libitum until DM intake stabilized (at a level of an average refusal of about $10 \%$ of the feed offered). During the five faecal collection periods, feed offered and refused, and feces of each animal were weighed daily, and samples taken for chemical analysis.

\subsection{Grazing Management and Measures on Dairy Cows}

The cows were milked twice per day in the milking parlor at 0600 and 1700 . Milk yield was measured daily and sampled on $\mathrm{d} 7$ to 11 of each collection period for fat and protein content determination. Throughout the experiment, cows were fed twice daily (at milking) $4 \mathrm{~kg}$ of barley malt sprout (90\% DM, 93\% OM, 25\% CP, $6.3 \mathrm{MJ}$ $\mathrm{NEL} / \mathrm{kg} \mathrm{DM})$. Samples of concentrate on offer and orts per cow, were weighted daily and composited weekly. Body weight was measured twice, on the $2 \mathrm{~d}$ immediately prior to the start of the first period and on the last $2 \mathrm{~d}$ of each grazing period. At the end of each grazing period, herds remained separate and grazed a non-study area of the farm sowed with the same hybrids.

\subsection{Chemical Analyses}

All the dried samples were ground through a $1 \mathrm{~mm}$ screen before chemical analysis. The dry matter (DM) concentration was determined by drying at $105^{\circ} \mathrm{C}$ in an oven for $24 \mathrm{~h}$ and ash content was determined by incineration at $600^{\circ} \mathrm{C}$ for $4 \mathrm{~h}$ for organic matter (OM) calculation. Crude protein (CP) content was determined using the Kjeldahl method (7.021 procedure) in AOAC [11]. Content of a neutral detergent fiber (aNDFom) was determined without sodium sulfite and with heat stable amylase. Acid detergent fiber (ADFom) and acid detergent lignin (lignin sa) were determined using sequential analysis and are expressed exclusive of residual ash [12]. An Ankom apparatus (Ankom 220, Fairport, NY, USA) was used for extraction and filtering. Gross Energy (GE) was determined using an adiabatic bomb calorimeter (GallenkampAutobomb; Loughborough, Leics, UK). Milk samples at every milking of each collection period were analyzed for fat, protein, and lactose content with infrared spectroscopy using a Bentley 2000 (BentleyInc. USA).

\subsection{Statistical Analysis}

All data were analyzed by ANOVA using the GLM procedure of SAS [13] and the model Yij $=\mu+\alpha \mathbf{i}+\beta \mathbf{j}+\varepsilon \mathbf{i j}$, where $\mathrm{Yij}=$ the dependent variable, $\mu$ = the overall mean, $\alpha \mathrm{i}=$ the effect of treatment $(\mathrm{i}=1,2), \beta \mathrm{j}=$ the effect of period $(\mathrm{j}=1$ to 3 ), and $\varepsilon \mathrm{ij}=$ the residual error. Pretreatment milk yield and milk composition were used as covariates. Initially the interaction treatment x period was included, and it was not significant, therefore it was not included in the final model. Results are reported as the least squares means. The least squares means were estimated and separated using the pdiff option. Probability values of $\mathrm{P}<0.05$ were used to define statistically significant results, with statistical trends being defined at $\mathrm{P}<0.10$. 


\section{Results and Discussion}

\subsection{Forage Characteristics and in vivo Digestibility of Sorghum Forage}

The average yield of DM per hectare, morphological and chemical compositions and in vivo digestibility of the sorghum hybrids over the three grazing periods, are shown in Table 1.

The BMR Sorghum hybrid has an average forage accumulation (1695 kg DM/ha) and a morphological composition (leaf:stem ratio of 1.5) similar to the CONTROL hybrid at the entrance to grazing. Those results contrast with data reported previously [1] [14], that the BMR trait is associated with a decrease in forage yield. CP content was low for both sorghum hybrids, this effect being more pronounced for the BMR hybrid, possibly related to a low supply of $\mathrm{N}$ fertilizer at sowing. Another parameter of great nutritional importance is the content of aNDFom and its components in the forage DM. Data in Table 1 indicate that the wall cell fractions, aNDFom and ADFom, were lower for the BMR hybrid but the Lignin(sa) fraction was higher (+2\%). Other studies have observed no difference in ADF and NDF concentrations between conventional and BMR-sorghum [9] [15]. It must be said, that the BMR sorghum was not compare to its correspondent normal one (the same genotype without the mutation) and so, the effect of the specific mutation is confounded with hybrid.GE content was not significant different between sorghum types.

The differences in chemical composition of green forages were reflected in differences in in vivo digestibility values. Apparent total tract digestibility of DM (+7.8\%) and OM (+8.2\%) were significantly higher for the BMR sorghum (Table 1), associated with increased total tract digestibility of NDF and ADF for the BMR treatment by $46(\mathrm{P}<0.05)$ and $56 \mathrm{~g} / \mathrm{kg} \mathrm{DM}(\mathrm{P}<0.01)$, respectively. Differences in cell wall digestibility should not be related to ADL content, but to variation in fiber composition among conventional and BMR sorghum as reflected by the higher ADL digestibility for the BMR hybrid $(+47 \mathrm{~g} / \mathrm{kg} \mathrm{DM}, \mathrm{P}<0.01)$. Higher cell wall in vivo digestibility was found by several authors [16] [17]. Vogel and Jung [18] have previously reported that besides lignin

Table 1. Effect of the sorghum hybrid on DM yield, plant height, morphological and chemical composition and in vivo digestibility (average values of three grazing periods).

\begin{tabular}{|c|c|c|c|}
\hline & \multicolumn{2}{|c|}{ Sorghum hybrid } & \multirow[b]{2}{*}{$P$} \\
\hline & $B M R^{\mathrm{a}}$ & CONTROL ${ }^{\mathrm{a}}$ & \\
\hline $\mathrm{DM}$ yield $(\mathrm{kg} \mathrm{DM} / \mathrm{ha})^{\mathrm{b}}$ & 1695 & 1746 & 0.8543 \\
\hline Plant height $(\mathrm{cm})$ & 75.7 & 73.0 & 0.8656 \\
\hline Tiller density (stems/m²) & 56 & 69 & 0.1803 \\
\hline \multicolumn{4}{|l|}{ Morphological composition (\% DM) ${ }^{\mathrm{b}}$} \\
\hline Leaves & 59.5 & 61.4 & 0.5546 \\
\hline Stems & 39.9 & 37.7 & 0.5255 \\
\hline Panicles & 0.6 & 0.7 & 0.9352 \\
\hline \multicolumn{4}{|l|}{ Chemical composition (g/kg DM) ${ }^{\mathrm{b}}$} \\
\hline $\mathrm{DM}(\mathrm{g} / \mathrm{kg})$ & 188 & 187 & 0.6250 \\
\hline $\mathrm{OM}$ & 918 & 912 & 0.4527 \\
\hline $\mathrm{CP}$ & 111 & 118 & 0.0001 \\
\hline aNDFom & 661 & 648 & 0.0485 \\
\hline Gross Energy (MJ/kg DM) & 17.2 & 16.8 & 0.1276 \\
\hline \multicolumn{4}{|l|}{ Apparent digestibility (g/kg) ${ }^{\mathrm{b}}$} \\
\hline $\mathrm{DM}$ & 650 & 603 & 0.0049 \\
\hline $\mathrm{OM}$ & 671 & 620 & 0.0027 \\
\hline aNDFom & 659 & 613 & 0.0115 \\
\hline ADFom & 658 & 602 & 0.0047 \\
\hline Lignin (sa) & 652 & 605 & 0.0042 \\
\hline Energy (kg J/MJ) & 666 & 629 & 0.0582 \\
\hline Total digestible DM (kg/ha) & 1056 & 985 & 0.6487 \\
\hline Total digestible aNDFom (kg/ha) ${ }^{\mathrm{b}}$ & 701 & 656 & 0.6735 \\
\hline
\end{tabular}

${ }^{a}$ BMR: brown mid-rib sorghum hybrid, CONTROL: commercial sorghum hybrid. ${ }^{b}$ above the cutting height $(10 \mathrm{~cm})$. 
content, BMR forage genotype may have altered lignin composition and cross-linking with wall carbohydrates, resulting in improved NDF and ADF digestibilities. Enhanced in vivo cell wall digestibility tended to increase energy digestibility $(+5.8 \%, \mathrm{P}<0.06)$. Finally, DE content was 11.5 and $10.5 \mathrm{MJ} / \mathrm{kg} \mathrm{DM}$ for BMR and CONTROL sorghum respectively. If we consider that the ratio Metabolizable Energy (ME): Digestible Energy (DE) is approximately 0.82, those values are in agreement with data reported by Miller and Stroup [19] (8.5 to 9.3 MJ ME/kg DM) and Moss [20] (8 to 9.5 MJ ME/kg DM) for sorghum forage with similar fiber content as the current study.

\subsection{Allowance and Characteristics of Forage Defoliated}

Forage allowance per cow was similar for both pastures, $24.9 \mathrm{~kg}$ DM/day on average at each grazing period (Table 2).

The depth of grazing was similar for both hybrids (34.1 cm on average). Nevertheless, due to the high level of herbage height in both sorghums, the post grazing height of the stems remained substantially higher $(40 \mathrm{~cm}$ on average) than the cutting height of the samples for chemical composition of the herbage on offer. Therefore, the composition of forage consumed by the cows should have been substantially different from that determined at the cutting height. In fact, by the analysis of the subsample composed of sections lying between the top of the stems and the mean height of forage after grazing, it appeared that defoliated forage was composed mainly of leaf (78\% on average compared to $60 \%$ leaves of the herbage offered) (Table 2).This might lead to an increase of the crude protein content of the cows' diet, higher than the protein content that is critical for ruminal digestion and the level which may affect the intake of the cow (below 12\% to $13 \%$ CP is reported as a value that can reduced cellulolysis [21]). In fact, the defoliated forage calculated as the product of the forage allowance per cow and the forage utilization, remained similar to the stipulated forage allocated per cow for both treatments as intended.

\subsection{Milk Production, Milk Composition and Live Weight Variation}

Milk production and 4\% FCM were 5\% greater $(\mathrm{P}<0.05)$ for cows grazing the BMR sorghum forage than for those grazing the standard sorghum forage (Table 3 ).

Milk fat content was not different among treatments, but production of milk fat was greater for the BMR sorghum versus the CONTROL sorghum treatment, which reflected the response observed in milk production. This experiment and others [9] [22] found that milk fat concentration did not change significantly between cows fed BMR sorghum and a conventional sorghum. It seems that enhanced NDF digestibility is associated to in situ extent of ruminal cell wall digestion significantly higher but with a rate of fiber digestion being no different between BMR than for standard sorghum [6] [9]. As a result, greater degradability may lead to increase production of fermentation acids, but with a relation between ketogenic:glucogenic volatile acids similar between both types of sorghum [9] [22].

Nevertheless, milk protein content presented a tendency to be slightly higher for cows grazing BMR sorghum $(\mathrm{P}<0.10)$ and consequently, protein production was also higher reflecting the response observed in milk

Table 2. Effect of the sorghum hybrid on utilization and morphological characteristics of forage defoliated by grazing dairy cows.

\begin{tabular}{|c|c|c|c|}
\hline & \multicolumn{2}{|c|}{ Sorghum hybrid } & \multirow[b]{2}{*}{$P$} \\
\hline & $B M R^{\mathrm{a}}$ & CONTROL ${ }^{\mathrm{a}}$ & \\
\hline Offered area (m²/cow/day) & 150 & 139 & 0.0990 \\
\hline Forage allowance (kg DM/cow/day) ${ }^{\mathrm{b}}$ & 25.2 & 24.6 & 0.8756 \\
\hline Depth of defoliation (cm) & 38.7 & 29.5 & 0.6464 \\
\hline Forage utilization (\%) & 67 & 64 & 0.7302 \\
\hline \multicolumn{4}{|l|}{ Morphological composition (\% DM) } \\
\hline Leaves & 77.8 & 79.6 & 0.7188 \\
\hline Stems & 22.2 & 19.1 & 0.7092 \\
\hline Panicles & 1.0 & 1.3 & 0.8393 \\
\hline
\end{tabular}

${ }^{\mathrm{a} B M R}$ : brown mid-rib sorghum hybrid, CONTROL: commercial sorghum hybrid. ${ }^{\mathrm{b}}$ above the cutting height $(10 \mathrm{~cm})$. 
Table 3. Effect of the sorghum hybrid on milk yield, milk composition, live weight variation and concentrate consumption by grazing dairy cows.

\begin{tabular}{cccc}
\hline & \multicolumn{3}{c}{ Sorghum hybrid } \\
\cline { 2 - 3 } & $B M R^{\mathrm{a}}$ & CONTROL $^{\mathrm{a}}$ & 0.0001 \\
\hline Milk yield (kg/day) & 19.9 & 19.1 & 0.8202 \\
Fat content (g/kg) & 35.2 & 35.0 & 0.0056 \\
Fat yield (g/day) & 714 & 662 & 0.0976 \\
Protein content (g/kg) & 30.9 & 30.5 & 0.0001 \\
Protein yield (g/day) & 620 & 584 & 0.0302 \\
Fat corrected milk (kg/day) & 18.5 & 17.8 & 0.0085 \\
Live weight variation (kg/day) & +0.193 & -0.326 & 0.0001 \\
Concentrate (kg DM/cow/day) & 3.1 & 3.5 & 0.0005 \\
\hline Efficiency of concentrate (kg FCM/kg DM) & 5.6 & 5.1 & \\
\hline
\end{tabular}

${ }^{a}$ BMR: brown mid-rib sorghum hybrid, CONTROL: commercial sorghum hybrid.

production ( +36 g/day) $(\mathrm{P}<0.01)$. Higher milk protein content might be attributed to a greater energy intake. Indeed, the BMR sorghum forage has a positive effect on the change in BW during the experiment $(+0.193$ $\mathrm{g} /$ day, $\mathrm{P}<0.01$ ), reflecting a positive energy balance. Such results might also be related to concentrate consumption, as cows on this treatment consumed less concentrate $(-0.4 \mathrm{~kg} / \mathrm{d}, \mathrm{P}<0.01)$. The efficiency of the concentrate expressed as FCM/kg DM concentrate was $13 \%$ increased $(\mathrm{P}<0.01)$ compared with CONTROL sorghum. Lower concentrate consumption on BMR forage diets, was previously reported [23]-[25].

Higher cell wall digestibility could lead to higher energy intake by cows, even if the DM intake has not been affected. Oba and Allen [26] reported that one unit increase in NDF digestibility in vitro or in situ was associated with a $0.25 \mathrm{~kg}$ increase in FCM. This relationship is slightly higher than our results $(+0.17 \mathrm{~kg}$ FCM/unit increase in DNDF), but it is possible that extra energy available was partitioned more into live weight gain than in milk production in accordance to results reported by Barriere and Argillier [27].

\subsection{Production per Hectare}

Forage yields are generally calculated and paid on the basis of DM yield per unit area. Therefore, a more significant parameter, which reflects the real yield at grazing, is the digestible DM yield achieved per hectare. Calculation of this parameter is presented in Table 1. It seems that both hybrids have reached similar values of digestible DM yield per hectare. Similar trend, but with lower values, was found with yield of digestible NDF per hectare.

Finally, milk yield per hectare during the grazing season might be estimated from Tables 2 and 3, as $3760 \mathrm{~kg}$ FCM/ha on average, but with lower use of inputs on the BMR treatment, as concentrate consumption was 135 $\mathrm{kg} \mathrm{DM} / \mathrm{ha}$ lower than in CONTROL treatment.

\section{Conclusion}

The BMR mutant of forage sorghum contained substantially less cell wall content than standard forage sorghum and resulted in greater fiber digestion, even though lignin content was similar for both sorghum types. The enhanced in vivo cell wall digestibility from BMR sorghum improved milk yield of mid-lactation dairy cows at grazing. Milk fat content was not affected by treatment, but the content of milk protein tended to increase, and so milk solids production per cow. Nevertheless, the DM yield per hectare, which is the most informative parameter for producers, was similar between sorghum types and consequently FCM yield per ha, but with a lower amount of concentrate supplied on the BMR treatment. In fact, a higher cell wall digestibility would lead to support a higher overall production and/or to provide less concentrate to animals and doing so, to increase the economic outcome. Further research with dairy cows in early lactation appears to be necessary to measure the impact of BMR sorghum for grazing animals with higher energy requirements.

\section{References}

[1] Pedersen, J.F. (1996) Annual Forages: New Approaches for C-4 Forages. In: Janick, J., Ed., Progress in New Crops, 
ASHS Press, Alexandria, 246-251.

[2] Porter, K.S., Axtell, J.D., Lechtenberg, V.L. and Colenbrander, V.F. (1978) Phenotype, Fiber Composition, and in Vitro Dry Matter Disappearance of Chemically Induced Brown Midrib (bmr) Mutants of Sorghum. Crop Science, 18, 205-208. http://dx.doi.org/10.2135/cropsci1978.0011183X001800020002x

[3] Fritz, J.O., Cantrell, R.P., Lechtenberg, V.L., Axtell, J.D. and Hertel, J.M. (1981) Brown Midrib Mutants in Sudangrass and Grain Sorghum. Crop Science, 21, 706-709. http://dx.doi.org/10.2135/cropsci1981.0011183X002100050019x

[4] Cherney, J.H., Cherney, D.J.R., Akin, D.E. and Axtell, J.D. (1991) Potential of Brown-Midrib, Low-Lignin Mutants for Improving Forage Quality. Advances in Agronomy, 46, 157-198. http://dx.doi.org/10.1016/S0065-2113(08)60580-5

[5] Fritz, J.O., Moore, K.J. and Jaster, E.H. (1990) Digestion Kinetics and Cell Wall Composition of Brown Midrib Sorghum $\times$ Sudangrass Morphological Components. Crop Science, 30, 213-219. http://dx.doi.org/10.2135/cropsci1990.0011183X003000010046x

[6] Grant, R.J., Haddad, S.G., Moore, K.J. and Pedersen, J.F. (1995) Brown Midrib Sorghum Silage for Midlactation Dairy Cows. Journal of Dairy Science, 78, 1970-1980. http://dx.doi.org/10.3168/jds.S0022-0302(95)76823-0

[7] Dann, H.M., Grant, R.J, Cotanch, K.W., Thomas, E.D., Ballard, C.S. and Rice, R. (2008) Comparison of Brown Midrib Sorghm-Sudangrass with Corn Silage on Lactational Performance and Nutrient Digestibility in Holstein Dairy Cows. Journal of Dairy Science, 91, 663-672. http://dx.doi.org/10.3168/jds.2007-0521

[8] Lusk, S.W., Karau, P.K., Balogu, D.O. and Gourley, L.M. (1984) Brown Midrib Sorghum or Corn Silage for Milk Production. Journal of Dairy Science, 67, 1739-1744. http://dx.doi.org/10.3168/jds.S0022-0302(84)81499-X

[9] Aydin, G., Grant, R.J. and O’Rear, J. (1999) Brown Midrib Sorghum in Diets for Lactating Dairy Cows. Journal of Dairy Science, 82, 2127-2135. http://dx.doi.org/10.3168/jds.S0022-0302(99)75456-1

[10] Leborgne, R. (1983) Antecedentes Tecnicos y Metodologia Para Presupuestacion en Establecimientos Lecheros. Edition Hemisferio Sur, Montevideo, 54p.

[11] AOAC, Association of Official Analytical Chemists (1980) Official Methods of Analysis. 16th Edition, AOAC, Arlington.

[12] Van Soest, P.J., Robertson, J.B. and Lewis, B.A. (1991) Methods of Dietary Fiber, Neutral Detergent Fiber and NonStarch Polysaccharides in Relation to Animal Nutrition. Journal of Dairy Science, 74, 3583-3597. http://dx.doi.org/10.3168/jds.S0022-0302(91)78551-2

[13] SAS Institute (2001) SAS System for Microsoft Windows. Release 8.2. SAS Institute Inc., Cary.

[14] Casler, M.D., Pederson, J.F. and Undersander, D.J. (2003) Forage Yield and Economic Losses Associated with the Brown Midrib Trait in Sudangrass. Crop Science, 43, 782-789. http://dx.doi.org/10.2135/cropsci2003.7820

[15] Ruiz, T.M., Bernal, E., Staples, C.R., Sollenberger, L.E. and Gallaher, R.N. (1995) Effect of Dietary Neutral Detergent Fiber Concentration and Forage Source on Performance of Lactating Cows. Journal of Dairy Science, 78, 305-319. http://dx.doi.org/10.3168/jds.S0022-0302(95)76639-5

[16] Wedig, C.L., Jaster, E.H., Moore, K.J. and Merchen, N.R. (1987) Rumen Turnover and Digestion of Normal and Brown Midrib Sorghum $\times$ Sudangrass Hybrid Silage in Dairy Cattle. Journal of Dairy Science, 70, 1220-1227. http://dx.doi.org/10.3168/jds.S0022-0302(87)80134-0

[17] Ledgerwood, D.N., DePeters, E.J., Robinson, P.H., Taylor, S.J. and Heguy, J.M. (2009) Assessment of a Brown Midrib (BMR) Mutant Gene on the Nutritive Value of Sudangrass Using in Vitro and in Vivo Techniques. Animal Feed Science and Technology, 150, 207-222. http://dx.doi.org/10.1016/j.anifeedsci.2008.10.001

[18] Vogel, K.P. and Jung, H.G. (2001) Genetic Modification of Herbaceous Plants for Feed and Fuel. Critical Reviews in Plant Sciences, 20, 15-49. http://dx.doi.org/10.1080/20013591099173

[19] Miller, F.R. and Stroup, J.A. (2004) Growth and Management of Sorghums for forage Production. Proceedings National Alfalfa Symposium, San Diego, 13-15 December, 149-158.

[20] Moss, R. (2009) Feed Requirement and Forage Quality. Queensland Government. Primary Industries and Fisheries. Department of Agriculture, Fisheries, and Forestry. http://www.daff.qld.gov.au/animal-industries/dairy/feed-and-nutrition/feed-requirements-and-forage-quality

[21] Poppi, D.P. and McLennan, S.R. (1995) Protein and Energy Utilisation by Ruminants at Pasture. Journal of Animal Science, 73, 278-290. http://www.journalofanimalscience.org/content/73/1/278

[22] Oliver, A.L., Grant, R.J., Pedersen, J.F. and O’Rear, J. (2004) Comparison of Brown Midrib-6 and -18 Forage Sorghum with Conventional Sorghum and Corn Silage in Diets of Lactating Dairy Cows. Journal of Dairy Science, 87, 637-644. http://dx.doi.org/10.3168/jds.S0022-0302(04)73206-3

[23] Hoden, A., Barrière, Y., Gallais, A., Huguet, L., Journet, M. and Mourguet, A. (1985) Le Maïs Brownmidrib Plante Entière. 3. Utilisation Sous Forme D'ensilage par les Vaches Laitières. Bulletin Technique CRZV Theix INRA, 60, 43- 
58.

[24] Bal, M.A., Shaver, R.D., Jirovec, A.G., Shinners, K.J. and Coorsmm, J.G. (2000) Crop Processing and Chop Length of Corn Silage: Effects on Intake, Digestion, and Milk Production by Dairy Cows. Journal of Dairy Science, 83, 12641273. http://dx.doi.org/10.3168/jds.S0022-0302(00)74993-9

[25] Oba, M. and Allen, M.S. (2000) Effects of Brown Midrib 3 Mutation in Corn Silage on Productivity of Dairy Cows Fed Two Concentrations of Dietary Neutral Detergent Fiber: 1. Feed Behavior and Nutrient Utilization. Journal of Dairy Science, 83, 1333-1341. http://dx.doi.org/10.3168/jds.S0022-0302(00)75000-4

[26] Oba, M. and Allen, M.S. (1999) Effects of Brown Midrib 3 Mutation in Corn Silage on Dry Matter Intake and Productivity of High Yielding Dairy Cows. Journal of Dairy Science, 82, 135-142. http://dx.doi.org/10.3168/jds.S0022-0302(99)75217-3

[27] Barrière, Y. and Argillier, O. (1993) Brown-Midrib Genes of Maize: A Review. Agronomy, 13, 865-876. http://dx.doi.org/10.1051/agro:19931001 